\title{
Inducible Sucrase Activity in Bacillus subtilis Distinct from Levan-sucrase
}

\author{
By LOUISE S. PRESTIDGE AND J. SPIZIZEN \\ Department of Microbiology, Scripps Clinic and Research Foundation, \\ La Jolla, California 92037, U.S.A.
}

(Accepted for publication 2 September 1969)

SUMMARY

An inducible sucrose hydrolysing enzyme has been found in Bacillus subtilis. The enzyme is intracellular, unstable in the absence of EDTA and its formation is repressed by glucose. These properties contrast with those of the levan-sucrase enzyme previously investigated in this organism.

\section{INTRODUCTION}

The occurrence of a sucrase without associated levan or dextran synthesizing activity has not been reported in Bacillus subtilis although separate enzymes for these two functions were suggested some time ago in Aerobacter strains (Hestrin, AvineriShapiro \& Ascher, 1943) and in B. megaterium (Forsyth \& Webley, 1950).

In this report evidence is presented for an inducible invertase-like activity in Bacillus subtilis which differs from the levan-sucrase (E.C. 2.4.I.I0) extensively studied by Delobbe \& Dedonder (1966), Dedonder (1960), Joyeux \& Seys-Borrel (1966) and Delobbe (1966). The lability, EDTA stabilizing effect, intracellular location and glucose repressibility of this sucrose hydrolysing activity differ from those reported for levan-sucrase.

\section{METHODS}

Bacterial strains. Bacillus subtilis 168 try-2, (designated ' $\mathrm{I} 68$ ' in the text) was from the collection of this laboratory while $\mathrm{BS} 5$ and $\mathrm{MC} 2$, kindly provided by Dr Dedonder, were mutants obtained from the I68 strain carried in his laboratory. These three strains were, respectively, low level inducible, high level inducible, and constitutive with regard to levan-sucrase production (personal communication from Dr Dedonder). They behave identically with respect to the newly detected sucrose hydrolyzing activity reported in this note.

Growth conditions and experimental techniques. Cultures were grown in either basic salts composition A (Dedonder, 1960) or B (Anagnostopoulos \& Spizizen, 196I), containing $0.5 \%$ carbon source, $20 \mu \mathrm{g} . / \mathrm{ml}$. L-tryptophan and $0.05 \%$ casein hydrolysate. Inducers were added to exponential growth-phase cultures and samples removed at intervals into iced tubes containing chloramphenicol sufficient to give a final concentration of $25-50 \mu \mathrm{g} . / \mathrm{ml}$. and EDTA, when used, at a final concentration of $0.0 \mathrm{I}-0.015 \mathrm{M}$. Suspensions were broken before assay either by lysozyme treatment or by sonic oscillation. Where necessary to eliminate compounds reacting in the assay, dialysis was carried out before determination of sucrose hydrolysis or levan synthesis activity. 
Assays. Sucrose hydrolysis activity was measured by glucose formation after incubation with $0.3-0.4 \mathrm{M}$-sucrose. Glucose was then determined by a modification of the method used by Messer \& Dahlqvist (1966) as follows. After incubation with sucrose a total volume of $0.5 \mathrm{ml}$. diluted sample was equilibrated at $37^{\circ}$ and $2.0 \mathrm{ml}$. assay reagent added. (The assay reagent contained $\mathrm{I} 0 \mu \mathrm{g} . / \mathrm{ml}$. glucose oxidase, $\mathrm{I} \mu \mathrm{g} . / \mathrm{ml}$. peroxidase and $50 \mu \mathrm{g} . / \mathrm{ml}$. $o$-dianisidine in $0.25 \mathrm{M}-\mathrm{PO}_{4}, \mathrm{pH}$ 6). After a suitable incubation period, the reaction was terminated and purple colour developed by the addition of $1.0 \mathrm{ml}$., $50 \% \mathrm{H}_{2} \mathrm{SO}_{4}$. Glucose concentrations of the samples were obtained by comparison of optical density readings at $530 \mathrm{~m} \mu$ with those of glucose standards run under the same conditions.

Levan production was estimated from turbidity readings of incubated samples in which levans of mol. wt $5 \times 10^{4}$ or larger were precipitated by the addition of 2 volumes of $95 \%$ EtOH.

Chemicals. Lysozyme grade I, glucose oxidase (Aspergillus niger) purified type II, peroxidase (horse-radish) type I, and $o$-diansidine were products of Sigma Chemical Company. Chloramphenicol was a gift of Parke Davis and Company. Other analytical grade reagents used were products of Fisher, Mallinkrodt, or Matheson Coleman and Bell.

\section{RESULTS}

Preliminary experiments of levan-sucrase induction in Bacillus subtilis strain BS 5 done in the presence of $0.5 \%$ glucose in a medium of salts composition ' $A$ ' were in qualitative agreement with data presented by Dedonder (1960) for the induction of levan-sucrase in a medium utilizing glycerol as a carbon source. Both sucrose hydrolysis and levan synthesis activity were optimally induced at the highest inducer concentration tested $\left(5 \times 1 \mathrm{IO}^{-2} \mathrm{M}\right)$, while comparatively negligible activities were found at inducer concentrations of $\mathrm{I} \times \mathrm{IO}^{-4} \mathrm{M}$ or lower.

However, when lactate was substituted for glycerol or glucose as carbon source in the same salts ' $A$ ' medium, it was found that both Bacillus subtilis I 68 and Bs 5 were capable of synthesizing significant levels of sucrose hydrolysis activity at inducer concentrations below $\mathrm{I} \times 1 \mathrm{IO}^{-4} \mathrm{M}$.

Levan synthesis activity could not be demonstrated in either strain by turbidity assay of samples induced at $\mathrm{I} \times \mathrm{IO}^{-4} \mathrm{M}$-sucrose although appreciable activities were found in Strain BS 5 at inducer concentrations of $0.5 \times 10^{-2} \mathrm{M}$ or higher.

Induction of sucrose hydrolysis activity at low sucrose concentration was dramatically increased in both BS 5 and 168 in lactate medium when salts ' $B$ ' was substituted for salts 'A'. However, regardless of the composition of the medium, the activity induced at low concentrations of sucrose proved to be quite unstable (unlike levan-sucrase), and various compounds were added in an attempt to stabilize the enzyme. Of the additions tested ( $\beta$-mercaptoethanol, cysteine, vitamin mixtures, trace metals, yeast extract, EDTA), only EDTA was found to have an appreciable effect on sucrose hydrolysis activity. Addition of $0.0 \mathrm{I}-0.015 \mathrm{M}$-EDTA increased activity and stabilized extracts for a short time during storage at $4^{\circ}$.

Studies of the EDTA-activated sucrase (which will henceforth be referred to as 'sucrase B') were then repeated in B. subtilis 168 and BS 5 under experimental conditions found optimal for induction and assay (i.e. the medium contained salts $B$ and lactate as carbon source, low sucrose inducer concentrations were employed and 
EDTA was added to broken-cell samples). The results contrasted strikingly with those previously obtained for levan-sucrose induction. A higher initial rate of enzyme induction was obtained with decreasing inducer concentration. The lowest concentration of sucrose tested $\left(1.46 \times 10^{-5} \mathrm{M}\right)$ acted as a more effective inducer than either of the two higher sucrose concentrations $\left(\mathrm{I} \cdot 17 \times 10^{-4} \mathrm{M}\right.$ or $\left.2.92 \times 10^{-4} \mathrm{M}\right)$ when early time samples prior to $30 \mathrm{~min}$. were compared.

The role of carbon source on induction suggested a catabolite repression effect. Addition of a low concentration of glucose $(40 \mu \mathrm{g}$. $/ \mathrm{ml}$.) was found sufficient to cause a lag period in initiation of sucrase B synthesis in BS 5 and 168 during growth on lactate. Addition of glucose to cultures in which induction was already in progress

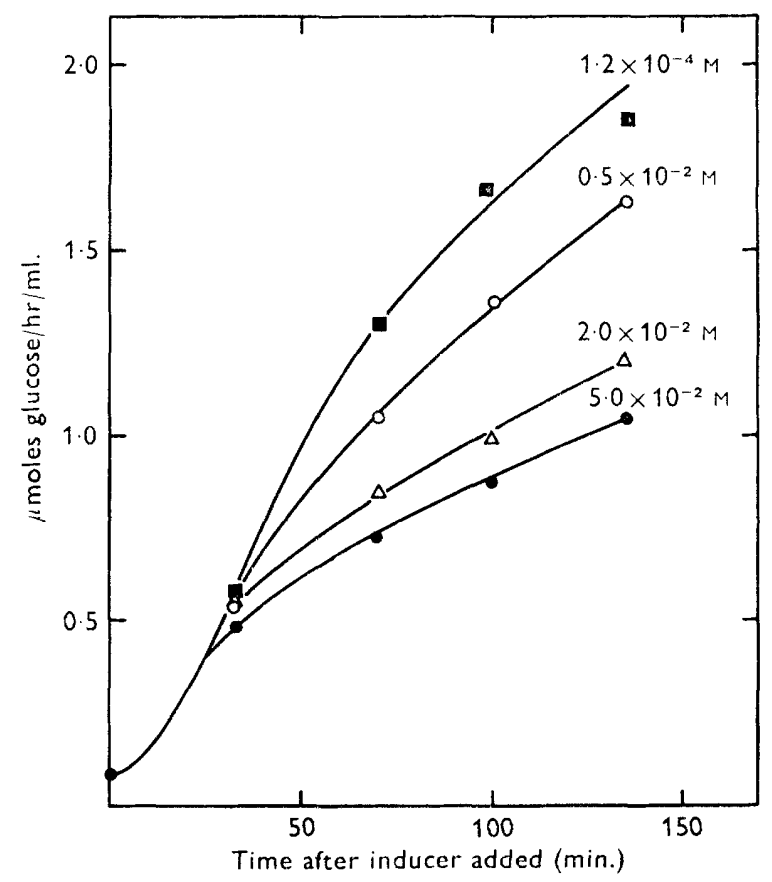

Fig. I. A culture of Bacillus subtilis strain Bs 5 in exponential growth phase at $30^{\circ}$ on salts A, $0.1 \%$ glycerol, $0.1 \%$ casein hydrolysate and $20 \mu \mathrm{g}$. L-tryptophan $/ \mathrm{ml}$. was divided among several flasks to which various concentrations of sucrose were added at o time. At intervals samples were removed and the organisms collected by centrifugation. Pellets were washed and resuspended in $0.02 \mathrm{M}$-sodium phosphate buffer $(\mathrm{pH} 6)+0.01 \mathrm{M}$-EDTA. (Resuspension volumes were adjusted to make all samples to the same concentration based on Klett Summerson readings made at the time of sampling.) After addition of $75 \mu \mathrm{g}$./lysozyme $/ \mathrm{ml}$., $15 \mu \mathrm{g}$. RNAse $/ \mathrm{ml}$. and $12 \mu \mathrm{g}$. DNAse $/ \mathrm{ml}$., a $30 \mathrm{~min}$. incubation was carried out at $37^{\circ}$ in order to lyse the organisms prior to subsequent determination of sucrose hydrolysis activity. No levan synthesis activity was detectable by turbidity assay.

caused abrupt and complete cessation of further enzyme production for a period of time was related to the amount of glucose added. This contrasts with levan-sucrase which is non-glucose repressible.

Sucrase B also differs from the predominantly extracellular levan-sucrase in that it appears to be completely intracellular. When sucrase B is induced by low concentration of inducer, and the cells and medium separated by centrifugation are assayed indepen- 
dently, all of the activity is found with the resuspended cells. Lysis by lysozyme or sonic treatment is required for full expression of the intracellular enzyme.

Finally, sucrase B can be most clearly distinguished by its different pattern of induction under conditions comparable to those used by Dedonder to study total levan-sucrase in the culture (i.e. salts $\mathrm{A}$ with glycerol carbon source). When BS 5 organisms were separated from the supernatant medium and maintained in the presence of EDTA their sucrose hydrolysis activity pattern was the reverse of that ascribed to levan-sucrase. Thus, at the lowest sucrose concentration $\left(\mathrm{I} \cdot 2 \times \mathrm{IO}^{-4} \mathrm{M}\right)$ maximum sucrose hydrolysis activity was produced without associated levan-synthesis activity. Figure I illustrates these results.

\section{DISCUSSION}

Two distinct sucrose hydrolysing activities can be induced in the same culture; one (sucrase B) being intracellular and produced with greatest activity at a lower inducer concentration ( $1 \cdot 17 \times 10^{-4} \mathrm{M}$ or less), and the other (levan-sucrase) found by Dedonder predominantly in the supernatant medium and present with maximal activity at high inducer concentrations $\left(5 \times \mathrm{IO}^{-2} \mathrm{M}\right.$ or higher $)$.

The two enzymes are presumably subject to different genetic controls. The MC2 mutant strain of Bacillus subtilis I68 (classified as levan-sucrase 'constitutive' by Dedonder) produced only a low level of levan-sucrase under conditions where levansucrase is fully induced in BS 5 . The induction pattern of sucrase B is, however, identical in both MC 2 and BS 5 .

These observations, together with observed differences in the properties of levansucrase and sucrase B with respect to the effects of EDTA and glucose repression provide strong evidence for the existence of two separate inducible sucrose hydrolysing enzymes in Bacillus subtilis.

The authors are indebted to Dr R. Dedonder for several of the strains used as well as for his interest in, and stimulating discussion of, the investigation. We are also appreciative of the helpful suggestions and criticism of Dr L. Rutberg made in the course of the work. This work was supported by Public Health Service Grant HD-02807 from the National Institute of Child Health and Human Development and by AEC contract AT(04-3)632.

\section{REFERENCES}

Anagnostopoulos, C. \& Spizizen, J. (1961). Requirements for transformation in Bacillus subtilis. J. Bact. 8r, 74I.

Dedonder, R. (1960). Le levane-sucrase de Bacillus subtilis. Bull. Soc. Chim. Biol. 42, 1745.

Delobbe, A. (1966). Etude de la fixation de fer sur la levane-sucrase de B. subtilis. C.r. hebd. Séanc., Paris 262, 2089.

Delobbe, A. \& Dedonder, R. (1966). Mise en evidence de deux formes de levane-sucrase de B. subtilis par action de la temperatue et de l'urée. C. r. hebd. Séanc. Acad. Sci., Paris 262, 2 187.

Forsyth, W. G. C. \& WeBLeY, D. M. (1950). The reducing sugars liberated during the bacterial synthesis of polysaccharides from sucrose. J. gen. Microbiol. 4, 87 .

Hestrin, S., Avineri-Shapiro, S. \& Aschner, M. (I943). The enzymatic production of levan. Biochem. J. 37, 450.

Joyeux, Y. \& Seys-Borrel, A. (I966). Localisation de la levane-sucrase de Bacillus subtilis. C. r. hebd. Séanc. Acad. Sci., Paris 263, 1891.

Messer, M. \& DAhlqvist, A. (I966). A one-step ultramicro method for the assay of intestinal disaccharidases. Analyt. Biochem. 14, 376. 